\title{
Performa Tiga Genotipe Itik Pedaging (Peking, PMp dan E-PMp) dengan Pemberian Dua Jenis Ransum selama Enam Minggu
}

\author{
(Performance of Three Genotypes of Broiler Ducks (Pekin, PMpP and E-PMp) with \\ the Administration Two Types of Formula Rations for Six Weeks Aged)
}

\author{
Purba M, Sinurat AP, Susanti T \\ Balai Penelitian Ternak, PO Box 221, Ciawi, Bogor 16002 \\ maijonpurba@gmail.com
}

\begin{abstract}
Information the nutritional requirements of local broiler ducks has been already available, but for Pekin ducks reared in Indonesia is still limited. The purpose of the study was to investigate the effect of two types formula rations (ration-A and ration-B) of feed on performance of three genotypes broiler ducks (Pekin, PMp and E-PMp). A total of 240 day-old ducks fed for six weeks were allocated into 6 treatments with 4 replicates and each replication consisted of 10 ducks. The study was conducted with completely randomized factorial design $3 \times 2$. The first factor was genotypes of broiler ducks (three genotypes) the second was type different feed formula (two types) nutrient content. Variables measured include feed consumption, body weight live, body weight gain and feed conversion ratio (FCR). Based on analysis of variances, interaction between genotype ducks with types of formulation did not significantly $(\mathrm{P}>0.05)$ affect to the performance. All variables measured were not significantly $(\mathrm{P}>0.05)$ affected by the feed treatments, but were significantly $(\mathrm{P}<0.01)$ affected by duck genotype. The average feed consumption, live body weight, body weight gain of Pekin ducks were significantly $(\mathrm{P}<0.01)$ higher than E-PMp and PMp ducks. FCR of Pekin and E-PMP broiler ducks was relatively similar (4.49 and 4.78 respectively), and markedly better than the FCR of PMp duck (5.29). It was concluded that the ration-B was relatively comparable effective as ration-A to the performance of all broiler ducks.
\end{abstract}

Key Words: Lysine, Energy, Ration, Broiler Ducks Performance

\begin{abstract}
ABSTRAK
Informasi kebutuhan gizi itik pedaging lokal sudah tersedia, akan tetapi informasi kebutuhan gizi itik Peking yang dipelihara di Indonesia masih terbatas. Tujuan penelitian ini adalah untuk menguji efek dua formula ransum yang berbeda kandungan gizi (lisin dan energi) terhadap konsumsi dan efisiensi ransum dari tiga genotipe itik (Peking, PMp dan E-PMp) umur enam minggu. Sebanyak 240 ekor itik sejak umur sehari dipelihara selama enam minggu dan dialokasikan ke dalam 6 perlakuan, 4 ulangan dan setiap ulangan terdiri dari 10 ekor itik. Rancangan penelitian adalah Rancangan Acak Lengkap pola faktorial $3 \times 2$. Faktor pertama adalah genotipe itik pedaging (tiga genotipe) dan faktor kedua adalah jenis formula ransum (ransum A dan ransum B). Peubah yang diamati mencakup konsumsi pakan, bobot badan hidup, pertambahan bobot badan dan feed conversion ratio (FCR) selama enam minggu. Hasil analisis sidik ragam menunjukkan bahwa interaksi antara formula ransum dengan genotipe itik tidak nyata $(P>0,05)$ berpengaruh terhadap performa itik. Semua peubah yang diamati tidak dipengaruhi $(\mathrm{P}>0,05)$ oleh pemberian ransum perlakuan, akan tetapi sangat nyata $(\mathrm{P}<0,01)$ dipengaruhi oleh genotipe itik. Rata-rata konsumsi pakan, bobot badan hidup dan PBB itik Peking sangat nyata $(\mathrm{P}<0,01)$ lebih tinggi dari itik PMp dan E-PMp. Rata-rata FCR itik Peking dan E-PMp tidak berbeda nyata berkisar dari 4,49-4,78 dan nyata lebih baik dibandingkan dengan FCR itik PMp $(5,29)$. Disimpulkan bahwa ransum B (rekomendasi Balitnak) sama efektivitasnya dengan ransum A (rekomendasi NRC) untuk menghasilkan konsumsi dan efisiensi ransum itik pedaging selama enam minggu.
\end{abstract}

Kata Kunci: Lisin, Energi, Ransum, Itik Pedaging, Performa 


\section{PENDAHULUAN}

Itik merupakan salah satu ternak unggas yang memiliki peranan penting sebagai penghasil daging dengan potensi pasar yang semakin berkembang. Itik juga merupakan salah satu ternak yang paling cepat berkembang dan paling efisien sebagai sumber protein hewani. Berdasarkan studi literatur, Adeola (2006) menyatakan bahwa ada empat jenis ternak unggas yang terkenal sebagai penghasil daging dan cukup dominan dijadikan sebagai sumber materi penelitian yakni: itik Peking, entog, itik serati (mule duck) dan itik Mallard. Itik Peking merupakan yang paling populer sebagai penghasil daging. Pada awalnya itik Peking diimpor dan masuk ke Indonesia untuk dipelihara dan selanjutnya berkembang biak dengan baik bahkan daya adaptasinya terhadap kondisi lingkungan di Indonesia sudah teruji. Salah satu sifat unggul dari itik Peking adalah ukuran dan bobot badan yang besar, pertumbuhannya cepat, bobot dan kualitas karkas yang tinggi. Rata-rata bobot badan akhir itik Peking terseleksi pada umur tujuh minggu sebesar 3.287 g/ekor dan persentase bobot daging dada sebesar 13\% (Pingel 2011). Rata-rata bobot badan itik Peking pada umur 42 hari mampu mencapai $3,4 \mathrm{~kg}$, pertambahan bobot badan sebesar 102,6 g/hari dengan rata-rata bobot karkas sebesar 76,2\% (Xie et al. 2014).

Selain itik Peking, Balai Penelitian Ternak (Balitnak) juga telah melaksanakan penelitian terhadap beberapa jenis itik yang bermanfaat sebagai penghasil daging yakni itik PMp dan E-PMp. Itik PMp merupakan hasil persilangan dari itik Peking jantan dengan itik Mojosari betina putih dan merupakan galur baru hasil produk Balitnak. Selain dapat berfungsi sebagai penghasil daging, itik PMp juga memiliki potensi tinggi sebagai penghasil telur. Rata-rata produksi telur bisa mencapai 67-70\% per tahun (Purba et al. 2015). Itik pedaging lainnya yang juga diteliti dan dikembangkan oleh Balitnak adalah itik E-PMp. Itik E-PMp tersebut merupakan hasil persilangan dari entog jantan dengan itik PMp betina. Secara biologis itik E-PMp memiliki (mewarisi) sifat dari tiga genotipe induknya yakni entog, itik Peking dan itik Mojosari putih. Sifat-sifat unggul yang dimiliki itik E-PMp antara lain pertumbuhannya cepat, ukuran tubuh besar dan memiliki otot atau daging yang tebal, warna bulu bervariasi (campuran warna bulu putih dan hitam), bobot karkas tinggi dan warna karkas putih bersih (Purba \& Prasetyo 2014). Ketiga genotipe itik tersebut dipelihara dan diseleksi dengan intensif untuk menghasilkan turunan yang unggul.

Informasi kebutuhan gizi khususnya untuk itik pedaging lokal sudah ada, akan tetapi informasi kebutuhan gizi itik Peking yang dipelihara di Indonesia masih terbatas. Minimnya informasi tersebut juga dilaporkan oleh peneliti lainnya yakni Adeola (2006); Liu \& Niu (2008); Choo et al. (2014). Kebutuhan gizi untuk itik baik dalam kegiatan penelitian maupun dalam usaha budidaya itik cenderung mengacu kepada rekomendasi NRC (1994) maupun Chen (1996). Kebutuhan gizi berupa protein dan energi itik Peking umur 0-2 minggu masing-masing sebesar $22 \%$ dan $2.900 \mathrm{kkal} / \mathrm{kg}$, sedangkan pada umur 27 minggu masing-masing sebesar $16 \%$ dan $3.000 \mathrm{kkal} / \mathrm{kg}$ (NRC 1994). Feed conversion ratio (FCR) itik baik sebagai tipe pedaging maupun petelur masih tergolong tinggi. Ratarata nilai FCR itik Serati periode starter 2,69, sedangkan periode finisher berkisar 4,154,29 (Ketaren et al. 2011). Nilai FCR yang masih tinggi pada itik pedaging merupakan salah satu permasalahan pokok mengingat faktor pakan bisa mencapai $65-70 \%$ dari biaya total produksi pemeliharaan itik.

Kebutuhan energi dan asam amino lisin yang paling baik untuk pertambahan bobot badan dan FCR itik pedaging E-PMp fase starter adalah sebesar $2.900 \mathrm{kkal} / \mathrm{kg}$ dan 1,15\%, sedangkan fase finisher masing-masing sebesar $2.700 \mathrm{kkal} / \mathrm{kg}$ dan $0,80 \%$ (Ketaren et al. 2011). Kandungan gizi berupa protein dan energi dalam pakan peranannya sangat penting untuk memacu pertumbuhan dan produksi yang maksimal pada itik. Kebutuhan protein dan energi pada ternak unggas ditetapkan berdasarkan umur, jenis maupun ukuran tubuh 
ternak. NRC (1994) memberi rekomendasi bahwa kebutuhan gizi itik Peking umur 0-2 minggu adalah sebesar $22 \%$ protein dan $2.900 \mathrm{kkal} / \mathrm{kg}$ energi dalam pakan. Kebutuhan gizi itik Peking pada umur 2-7 minggu adalah sebesar $16 \%$ protein dan $3.000 \mathrm{kkal} / \mathrm{kg}$ energi.

Kandungan gizi ransum yang berbeda dan diuji cobakan dalam penelitian ini adalah kandungan asam amino lisin dan energi ransum. Lisin merupakan salah satu asam amino esensial bagi ternak unggas. Peranannya sangat penting untuk memacu pertumbuhan ternak. Kebutuhan lisin pada itik Peking umur 0-2 minggu adalah sebesar 0,90\%, sedangkan pada umur 2-7 minggu sebesar 0,65\% (NRC 1994). Defisiensi lisin dalam ransum unggas dapat menghambat pertumbuhan, konsumsi dan efisiensi ransum yang tinggi dan dapat menurunkan bobot maupun kualitas karkas. Selain asam amino lisin, kebutuhan energi dalam ransum khususnya untuk unggas sangat penting. Defisiensi energi dalam ransum dapat mengakibatkan menurunnya pertumbuhan, produksi ternak dan mengakibatkan konsumsi ransum yang meningkat sehingga tidak efisien dalam penggunaan ransum. Jumlah konsumsi ternak unggas akan semakin meningkat apabila kandungan gizi berupa protein dan energi dalam ransum rendah (Leeson et al. 1996; Hernandez et al. 2004). Dalam segi ekonomi, setiap peningkatan kebutuhan energi dalam ransum dapat mengakibatkan kenaikan biaya produksi. Oleh sebab itu, peranan kecukupan gizi khususnya asam amino lisin dan energi yang seimbang dalam ransum sangat perlu diperhatikan.

Level penggunaan lisin dan energi yang paling optimum untuk itik pedaging lokal masih perlu dipertimbangkan dan diteliti untuk menurunkan konsumsi dan efisiensi ransum pada ketiga genotipe itik yang diteliti. Oleh sebab itu, perlu dilakukan penelitian tentang kebutuhan gizi itik pedaging yang telah dilakukan Balitnak dan diuji cobakan kepada itik Peking dan membandingkannya dengan kebutuhan gizi itik Peking sesuai rekomendasi NRC (1994). Makalah ini bertujuan mengevaluasi kedua jenis ransum perlakuan terhadap performa pada itik Peking, PMp dan E-PMp pada umur enam minggu.

\section{MATERI DAN METODE}

Materi yang digunakan dalam penelitian ini adalah tiga genotipe itik pedaging yaitu Peking, PMp dan E-PMp. Rancangan penelitian yang digunakan adalah Rancangan Acak Lengkap (RAL) pola faktorial $3 \times 2$. Faktor pertama adalah tiga genotipe itik dan faktor kedua adalah dua jenis formula ransum. Kedua jenis formula ransum yang digunakan adalah: (1) Formulasi ransum sesuai rekomendasi NRC (1994) yang disebut sebagai ransum A; dan (2) Formulasi ransum terbaik berdasarkan asam amino ileal digestibility hasil penelitian Balitnak (Ketaren et al. 2011) yang disebut sebagai ransum B. Formula dan kandungan gizi ransum yang digunakan dalam penelitian ini dicantumkan pada Tabel 1.

Setiap ransum perlakuan memiliki empat ulangan dan setiap ulangan terdiri atas 10 ekor itik, sehingga jumlah itik sebanyak 240 ekor. Itik dipelihara sejak umur 0-6 minggu. Pada umur 0-4 minggu seluruh itik dipelihara di kandang brooder yang diberi lampu pemanas, tempat pakan dan minum. Pada saat itik berumur empat minggu itik dipindahkan ke kandang berbentuk pen yang beralaskan acrilic. Tempat pakan dan air minum di setiap pen juga disediakan. Pakan diberikan dua kali sehari yakni waktu pagi dan sore hari sedangkan air minum ad libitum. Pakan starter diberikan dari umur 0-4 minggu, sedangkan pakan finisher diberikan setelah itik berumur empat minggu. Itik ditimbang setiap minggu, demikian juga dengan sisa pakan untuk memperoleh data bobot badan mingguan dan konsumsi serta konversi ransum itik. Data yang diperoleh dianalisis dengan prosedur General Linear Model (GLM) dengan bantuan program Statistical Analisys System (SAS 1997). 
Tabel 1. Bahan, formulasi dan kandungan gizi ransum perlakuan

\begin{tabular}{|c|c|c|c|c|}
\hline \multirow{3}{*}{ Bahan } & \multicolumn{2}{|c|}{ Ransum starter } & \multicolumn{2}{|c|}{ Ransum finisher } \\
\hline & Ransum A & Ransum B & Ransum A & Ransum B \\
\hline & \multicolumn{4}{|c|}{ 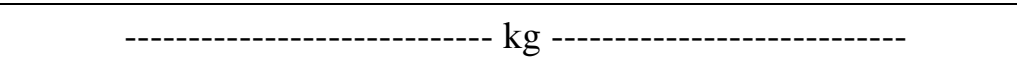 } \\
\hline Dedak & 18,39 & 22,20 & 29,90 & 35,52 \\
\hline Jagung & 37,00 & 43,80 & 43,03 & 47,11 \\
\hline Bungkil kedele & 29,00 & 22,00 & 13,50 & 14,10 \\
\hline Tepung ikan & 6,70 & 3,00 & 4,00 & 2,00 \\
\hline MBM & 2,00 & 2,00 & 2,00 & 2,00 \\
\hline Methionin & 0,18 & 0,15 & 0,14 & 0,17 \\
\hline Lysin & 0,00 & 0,57 & 0,10 & 0,32 \\
\hline Premiks & 0,20 & 0,25 & 0,20 & 0,25 \\
\hline $\mathrm{CPO}$ & 5,00 & 4,50 & 5,60 & 0,00 \\
\hline DCP & 0,74 & 0,74 & 0,74 & 0,74 \\
\hline Kapur & 0,59 & 0,59 & 0,59 & 0,59 \\
\hline Garam & 0,20 & 0,20 & 0,20 & 0,20 \\
\hline Total & 100,00 & 100,00 & 100,00 & 100,00 \\
\hline \multicolumn{5}{|c|}{ Kandungan gizi (hasil perhitungan) } \\
\hline Protein $(\%)$ & 22,00 & 19,00 & 16,00 & 16,23 \\
\hline $\operatorname{Lisin}(\%)$ & 0,90 & 1,15 & 0,65 & 0,80 \\
\hline Energi $(\mathrm{kkal} / \mathrm{kg})$ & $2.913,00$ & $2.917,00$ & $3.000,00$ & $2.705,00$ \\
\hline Serat kasar (\%) & 3,93 & 4,32 & 5,17 & 5,55 \\
\hline Kalsium (\%) & 1,33 & 1,04 & 1,11 & 0,98 \\
\hline Fosfor (\%) & 0,80 & 0,72 & 0,77 & 0,75 \\
\hline
\end{tabular}

Ransum A (sesuai rekomendasi NRC 1994); Ransum B (sesuai rekomendasi Balitnak 2010); MBM: Meat bone meal; CPO: Crude palm oil; DCP: Dikalsium fosfat

\section{HASIL DAN PEMBAHASAN}

\section{Pengaruh ransum perlakuan terhadap konsumsi pakan itik}

Rata-rata konsumsi pakan dari ketiga genotipe itik pedaging dengan pemberian dua jenis ransum perlakuan (ransum A dan ransum B) selama enam minggu disajikan dalam Tabel 2. Berdasarkan hasil analisis sidik ragam interaksi antara jenis ransum dengan genotipe itik tidak nyata berpengaruh $(\mathrm{P}>0,05)$ terhadap tingkat konsumsi. Begitu pula perlakuan jenis ransum tidak nyata berpengaruh $(\mathrm{P}>0,05)$ terhadap konsumsi pakan, akan tetapi sangat nyata $(\mathrm{P}<0,01)$ dipengaruhi oleh genotipe itik. Rata-rata konsumsi ransum itik Peking sangat nyata $(\mathrm{P}<0,01)$ lebih tinggi bila dibandingkan dengan kedua genotipe itik lainnya. Hasil analisis statistik juga memperlihatkan bahwa rata-rata konsumsi ransum itik E-PMp nyata $(\mathrm{P}<0,05)$ lebih rendah (lebih baik) bila dibandingkan dengan konsumsi ransum itik $\mathrm{PMp}$ bahkan sangat nyata $(\mathrm{P}<0,01)$ dibandingkan dengan konsumsi ransum itik Peking. Rata-rata konsumsi ransum yang lebih tinggi pada itik Peking dapat disebabkan oleh berbagai faktor antara lain ukuran/bobot tubuh itik. Ukuran/bobot tubuh itik Peking lebih besar dibandingkan dengan kedua genotipe itik lainnya. Ukuran/bobot 
tubuh yang lebih besar membutuhkan jumlah pakan yang lebih banyak terutama untuk mengimbangi pertumbuhan maupun maintenance tubuh itik. Diduga kuat adalah sifat genetik yang positif tentang berupa pemanfaatan gizi yang terkandung dalam pakan telah berjalan dengan baik melalui proses pencernaan dan penyerapan oleh itik.

Tabel 2. Rata-rata konsumsi ransum dari tiga genotipe itik pedaging dengan pemberian dua jenis ransum perlakuan selama enam minggu (g/ekor)

\begin{tabular}{lccc}
\hline \hline Genotipe & Ransum A (g/ekor \pm SE) & Ransum B (g/ekor \pm SE) & Rata-rata (g/ekor \pm SE) \\
\hline Peking & $7.600 \pm 59,13$ & $7.602 \pm 59,13$ & $7.601^{\mathrm{c}} \pm 41,81$ \\
PMp & $6.412 \pm 59,13$ & $6.616 \pm 59,13$ & $6.514^{\mathrm{b}} \pm 41,81$ \\
E-PMp & $5.769 \pm 59,13$ & $5.753 \pm 59,13$ & $5.761^{\mathrm{a}} \pm 41,81$ \\
\hline Rata-rata & $6.594 \pm 34,14$ & $6.657 \pm 34,14$ & \\
\hline
\end{tabular}

Huruf superscript yang berbeda pada setiap kolom menunjukkan perbedaan yang sangat nyata $(\mathrm{P}<0,01)$; Ransum A (formulasi NRC 1994); Ransum B (formulasi Balitnak); SE: Standard error

Konsumsi ransum dapat dipengaruhi oleh berbagai faktor, salah satu faktor utama adalah kualitas ransum khususnya kandungan gizi yang terkandung di dalamnya (Hernandez et al. 2004; Ghaffari et al. 2007; Fan et al. 2008). Kandungan gizi berupa lisin dan energi yang berasal dari ransum yang dikonsumsi diduga telah mencukupi untuk proses pertumbuhan maupun untuk maintenance itik. Peningkatan kandungan energi yang optimal dalam ransum dapat menurunkan konsumsi ransum, sebaliknya apabila kandungan energi rendah (tidak mencukupi kebutuhan) akan dapat mengakibatkan peningkatan konsumsi pakan bahkan cenderung mengakibatkan penimbunan lemak pada jaringan perut maupun pada daging/karkas Shelton et al. (2003), Grobas et al. (1999) maupun PerezBonilla et al. (2012).

Pemberian ransum yang minim dengan kandungan gizi berupa asam amino lisin dapat mengakibatkan penurunan performa pada ternak unggas (Shelton et al. 2003; Garcia \& Batal 2006; Dozier et al. 2008). Kebutuhan gizi untuk itik lokal masih sering mengacu kepada rekomendasi NRC (1994) maupun Chen (1996). Rata-rata konsumsi ransum itik yang dihasilkan dari kedua jenis ransum oleh setiap genotipe itik pada periode starter relatif sama. Kadar protein ransum dapat diturunkan sampai batas tertentu (kebutuhan) akan tetapi kadar asam amino lisin harus diperhatikan dan tidak boleh kurang dari jumlah yang dibutuhkan. Hasil penelitian ini menunjukkan bahwa pada periode starter (0-4 minggu) kandungan protein pakan sebesar 19\% dan lisin 1,15\% dianggap cukup untuk mendukung pertumbuhan itik. Selanjutnya Tabel 2 juga menunjukkan bahwa penurunan kandungan energi ransum dari $3.000 \mathrm{kkal} / \mathrm{kg}$ menjadi $2.705 \mathrm{kkal}$ dengan kadar lisin 0,80\% juga telah memenuhi kebutuhan untuk menopang pertumbuhan pada ketiga genotipe itik.

Hasil penelitian ini juga memberi gambaran bahwa efektivitas ransum A dengan ransum $\mathrm{B}$ relatif sama pada ketiga genotipe itik untuk menghasilkan konsumsi pakan selama umur enam minggu.

\section{Pengaruh ransum perlakuan terhadap bobot badan hidup itik}

Berdasarkan hasil analisis sidik ragam, interaksi antara jenis ransum perlakuan dengan genotipe itik tidak nyata $(\mathrm{P}>0,05)$ berpengaruh terhadap bobot badan hidup itik. Pemberian kedua jenis ransum perlakuan juga tidak nyata $(\mathrm{P}>0,05)$ berpengaruh terhadap bobot badan hidup itik, akan tetapi perbedaan genotipe sangat nyata $(\mathrm{P}<0,01)$ berpengaruh. Berdasarkan hasil analisis statistik rata-rata bobot hidup itik Peking sangat nyata $(\mathrm{P}<0,01)$ lebih tinggi 
dibandingkan dengan bobot hidup kedua genotipe itik lainnya. Rata-rata bobot badan hidup itik Peking dengan pemberian ransum perlakuan sebesar 1.755 g/ekor sedangkan pada itik PMp dan E-PMp masing-masing sebesar 1.284 dan 1.259 g/ekor (Tabel 3).

Tabel 3. Rata-rata bobot badan hidup dari tiga genotipe itik dengan pemberian dua jenis ransum perlakuan selama enam minggu (g/ekor)

\begin{tabular}{lccc}
\hline \hline Genotipe & Ransum A (g/ekor \pm SE) & Ransum B (g/ekor \pm SE) & Rata-rata (g/ekor \pm SE) \\
\hline Peking & $1.709 \pm 53,19$ & $1.801 \pm 53,19$ & $1.755^{\mathrm{c}} \pm 34,13$ \\
PMp & $1.293 \pm 53,19$ & $1.276 \pm 53,19$ & $1.284^{\mathrm{b}} \pm 34,13$ \\
E-PMp & $1.275 \pm 53,19$ & $1.243 \pm 53,19$ & $1.259^{\mathrm{b}} \pm 34,13$ \\
\hline Rata-rata & $1.425 \pm 23,12$ & $1.440 \pm 23,12$ & \\
\hline
\end{tabular}

Huruf superscript yang berbeda pada setiap kolom menunjukkan perbedaan yang sangat nyata $(\mathrm{P}<0,01)$; Ransum A (formulasi NRC 1994); Ransum B (formulasi Balitnak); SE: Standard error

Secara umum penyebab bobot badan hidup itik Peking yang lebih tinggi dibandingkan dengan itik PMp dan E-PMp adalah faktor genetik. Secara genetik pertumbuhan itik Peking tergolong cepat, ukuran tubuh yang lebih besar bila dibandingkan dengan kedua jenis itik lainnya. Peningkatan bobot tersebut diperkirakan pengaruh kandungan lisin yang semakin meningkat dalam ransum. Kandungan lisin yang semakin meningkat dalam ransum dapat meningkatkan pertumbuhan itik Peking yang dipelihara sejak umur 7-21 hari (Xie et al. 2009). Tingkat pertumbuhan yang cepat pada itik Peking juga telah dilaporkan oleh (Adeola 2006; Pingel 2011). Dilaporkan bahwa sifat genetik yang dimiliki oleh itik Peking tidak terlepas dari proses seleksi yang intensif dan terarah sehingga kualitas produksi yang dihasilkan juga menjadi semakin meningkat. Senada dengan Adeola (2006), peneliti lainnya yaitu Pingel (2011), juga memperkuat bahwa selain faktor genetik, faktor manajemen dan kandungan gizi pakan yang sesuai sangat berpengaruh terhadap performa bahkan terhadap kualitas karkas itik Peking (Xie et al. 2014; Dozier et al. 2008). Hasil penelitian ini juga memperlihatkan bahwa rata-rata bobot hidup itik PMp berbeda tidak nyata dengan itik E-PMp selama pemeliharaan enam minggu, walaupun itik PMp mewarisi sifat genetik yang berasal dari indukannya yakni itik Peking sebagai salah satu itik tipe itik pedaging yang terkenal. Hasil penelitian ini juga memberi gambaran bahwa efektivitas ransum B (Balitnak) dapat menyamai efektivitas ransum A (NRC 1994) untuk menghasilkan bobot badan hidup dari ketiga galur itik selama enam minggu.

\section{Pengaruh ransum perlakuan terhadap pertambahan bobot badan (PBB) itik}

Berdasarkan hasil analisis sidik ragam, interaksi antara jenis ransum perlakuan dengan genotipe itik tidak nyata $(\mathrm{P}>0,05)$ berpengaruh terhadap PBB itik selama enam minggu. Akan tetapi, perbedaan genotipe itik sangat nyata $(\mathrm{P}<0,01)$ berpengaruh. Rata-rata PBB itik Peking tampak lebih tinggi bila dibandingkan dengan PBB itik PMp maupun E-PMp (Tabel 4).

Pemberian kedua jenis ransum perlakuan tidak nyata $(\mathrm{P}>0,05)$ berpengaruh terhadap PBB itik. Hal ini memberi gambaran bahwa peranan lisin dan kandungan energi dalam ransum penelitian ini belum dapat membedakan PBB itik. Hasil ini berbeda dengan laporan Xie et al. (2009) yang menyatakan bahwa PBB itik Peking yang dipelihara sejak umur 7-21 hari menjadi semakin meningkat. Level lisin yang terkandung dalam ransum yang diberikan yakni 0,$65 ; 0,80 ; 0,90 ; 1,10$ dan 1,20\% (Xie et al. 2009). Salah satu faktor utama untuk meningkatkan PBB pada unggas adalah kualitas pakan termasuk kandungan 
gizi yang ada di dalamnya (Hernandez et al. 2004). Pertumbuhan yang normal pada itik dapat dicapai apabila ransum yang dikonsumsi mengandung energi, protein (asam amino), vitamin dan mineral yang mencukupi (Shelton et al. 2003; Adeola 2006; Kamran et al. 2008). Ransum yang mengandung energi rendah apabila dikonsumsi secara berkelanjutan dapat mengakibatkan pertumbuhan yang lambat pada itik. Pertumbuhan yang lambat pada itik bisa berdampak terhadap produksi telur maupun daging yang dihasilkan menjadi rendah (Shelton et al. 2003).

Tabel 4. Rataan pertambahan bobot badan (PBB) dari tiga genotipe itik yang diberi dua jenis ransum perlakuan selama enam minggu (g/ekor)

\begin{tabular}{lccc}
\hline Genotipe & Ransum A (g/ekor \pm SE) & Ransum B (g/ekor \pm SE) & Rata-rata (g/ekor \pm SE) \\
\hline Peking & $1.653 \pm 33,19$ & $1.745 \pm 33,19$ & $1.699^{\mathrm{c}} \pm 23,47$ \\
PMp & $1.245 \pm 33,19$ & $1.229 \pm 33,19$ & $1.237^{\mathrm{b}} \pm 23,47$ \\
E-PMp & $1.226 \pm 33,19$ & $1.193 \pm 33,19$ & $1.209^{\mathrm{b}} \pm 23,47$ \\
\hline Rata-rata & $1.374 \pm 19,17$ & $1.389 \pm 19,16$ & \\
\hline
\end{tabular}

Huruf superscript yang berbeda pada setiap kolom menunjukkan perbedaan yang sangat nyata ( $\mathrm{P}<0,01)$; Ransum A (formulasi NRC 1994); Ransum B (formulasi Balitnak); SE: Standard error

Hasil penelitian ini memberi gambaran bahwa PBB itik Peking lebih tinggi dibandingkan dengan itik PMp dan E-PMp, akan tetapi ransum B relatif sama efektivitasnya dengan ransum A untuk menghasilkan PBB pada setiap genotipe itik selama enam minggu.

\section{Pengaruh ransum perlakuan terhadap feed conversion ratio (FCR) itik}

Rataan FCR dari ketiga genotipe itik dengan pemberian dua jenis ransum perlakuan selama enam minggu dicantumkan dalam Tabel 5. Berdasarkan hasil analisis sidik ragam, interaksi antara jenis ransum perlakuan dengan genotipe itik tidak nyata $(\mathrm{P}>0,05)$ berpengaruh terhadap FCR itik. Pemberian kedua jenis ransum perlakuan terhadap ketiga genotipe itik tidak nyata $(\mathrm{P}>0,05)$ berpengaruh terhadap FCR itik, akan tetapi genotipe itik berpengaruh nyata $(\mathrm{P}<0,05)$. Berdasarkan hasil analisis statistik rata-rata FCR itik PMp nyata $(\mathrm{P}<0,05)$ lebih tinggi (lebih buruk) dibandingkan dengan FCR dari kedua genotipe itik lainnya. Rata-rata FCR itik Peking relatif sama dengan FCR itik E-PMp dan nyata $(\mathrm{P}<0,05)$ lebih rendah (lebih baik) bila dibandingkan dengan FCR itik PMp selama enam minggu pemeliharaan.

Tabel 5. Rata-rata FCR ketiga genotipe itik yang diberi dua jenis ransum perlakuan selama enam minggu (g/ekor)

\begin{tabular}{lccc}
\hline \hline Genotipe & Ransum A (g/ekor \pm SE) & Ransum B (g/ekor \pm SE) & Rata-rata (g/ekor \pm SE) \\
\hline Peking & $4,61 \pm 0,13$ & $4,36 \pm 0,13$ & $4,49^{\mathrm{a}} \pm 0,09$ \\
PMp & $5,15 \pm 0,13$ & $5,41 \pm 0,13$ & $5,29^{\mathrm{b}} \pm 0,09$ \\
E-PMp & $4,72 \pm 0,13$ & $4,83 \pm 0,13$ & $4,78^{\mathrm{a}} \pm 0,09$ \\
\hline Rata-rata & $4,83 \pm 0,08$ & $4,87 \pm 0,08$ & \\
\hline
\end{tabular}

Huruf superscript yang berbeda pada setiap kolom menunjukkan perbedaan yang sangat nyata $(\mathrm{P}<0,01)$; Ransum A (formulasi NRC 1994); Ransum B (formulasi Balitnak); SE: Standard error 
Pemberian kedua jenis ransum perlakuan selama umur enam minggu, rata-rata FCR itik Peking relatif sama dengan FCR itik E-PMp karena secara statistik interaksi tidak berbeda nyata $(\mathrm{P}>0,05)$. Apabila dilihat pada Tabel 5 juga tampak bahwa FCR itik Peking yang diberi ransum $\mathrm{B}$ relatif sama bila dibandingkan dengan pemberian ransum A karena berdasarkan hasil analisis statistik tidak berbeda nyata. Artinya, ransum B (rekomendasi Balitnak), relatif sama efektivitasnya dengan ransum A untuk menghasilkan FCR dari ketiga genotipe itik selama umur enam minggu.

\section{KESIMPULAN}

Ransum A dan ransum B memiliki efektivitas yang sama untuk menghasilkan performa khususnya konsumsi dan efisiensi ransum pada ketiga genotipe itik. Peformans dari ketiga genotipe itik tidak nyata dipengaruhi oleh kedua jenis ransum perlakuan, akan tetapi sangat nyata dipengaruhi oleh genotipe itik. Genotipe itik yang paling baik untuk menghasilkan FCR selama enam minggu adalah itik Peking.

\section{UCAPAN TERIMA KASIH}

Penulis mengucapkan terima kasih yang sebesar-besarnya kepada tenaga teknisi kandang itik Balitnak (Miftah, Dedi Muslih, Sumardi, Saepulloh, Anto dan Asep) atas bantuannya selama penelitian berlangsung.

\section{DAFTAR PUSTAKA}

Adeola O. 2006. Review of research in duck nutrient utilization. Int J Poult Sci. 5:201-204.

Chen TF. 1996. Nutrition and feedstuffs of ducks. In: The training course for duck production and management. Taipei (Taiwan): Livestock Research Institute, Monograph No. 46. Committee of International Technical Cooperation.

Choo YK, Kwon HJ, Oh ST, Kang CW, Kim HK, Hong EC, Heo KN, Lee SK, An BK. 2014. Growth performance and carcass characteristics of Korean native ducks fed diets with varying levels of limiting amino acids. Asian Aust J Anim Sci. 27:518-523.

Dozier WA, Corzo A, Kidd MT and Schilling MW. 2008. Dietary digestible lysine requirements of male and female broilers from forty-nine to sixty-three days of age. Poult Sci. 87:1385-1391.

Fan HP, Xie M, Wang WW, Hou SS, Huang W. 2008. Effect of dietary energy on growth performance and carcass quality of white growing Pekin ducks from two to six weeks of age. Poult Sci. 87:1162-1164.

Garcia A, Batal AB. 2006. Changes in the digestible lysine and sulfur amino acid needs of broiler chicks during the first three weeks posthaching. Poult Sci. 84:1350-1355.

Ghaffari M, Shivazad M, Zaghary M, Taherkhani R. 2007. Effect different level of metabolizable energy and formulation of diet based on digestible and total amino acid requirements on performance of male broiler. Int J Poult Sci. 6:276-279.

Grobas S, Mendez J, De Blas C, Mateos GG. 1999. Laying hens productivity as affected by energy supplemented fat and linoleic acid concentration of the diet. Poult Sci. 78:1542-1551.

Hernandez F, Madrid J, Garcia V, Orengo J, Megias MD. 2004. Influence of two plant extracts on broilers performance, digestibility, and digestive organ size. Poult Sci. 83:169-174.

Kamran Z, Sarwar M, Nisa M, Nadeem MA, Mahmood S, Babar ME, Ahmed S. 2008. Effect of low-protein diets having constant energy-to-protein ratio on performance and carcass characteristics of broiler chickens from one to thirthy-five days of age. Poult Sci. 87:468-474. 
Ketaren PP, Sinurat AP, Prasetyo LH, Rahardjo YC, Purba M. 2011. Effect of lysine and metabolizable energy levels on productivity performance of Mule ducks. In: Proceedings of the 3rd International Conference, on Sustainable Animal Agriculture for Developing Countries. Nakhon Ratchasima, July 26-29, 2011. Nakhon Ratchasima (Thailand).

Leeson S, Caston L, Summers JD. 1996. Broiler response to dietary energy. Poult Sci. 75:529-535.

Liu F, Niu Z. 2008. Carcass quality of different meat-typed chickens when achieve a common physiological body weight. Int J Poult Sci. 7:319-322.

NRC. 1994. Nutrient requirement of poultry.Washington DC (US): National Academy Press.

Perez-Bonilla A, Novoa S, Garcia J, Mohiti-Asli M, Frikha, Mateos GG. 2012. Effect of energy concentration of the diet on productive performance and egg quality of brown egg-laying hens differing in initial body weight. Poult Sci. 91:3156-3166.

Purba M, Prasetyo LH. 2014. Growth and carcass production responses of EPMp ducks to various levels of crude fiber and protein in the diet. JITV. 19:220-230.

Purba M, Prasetyo LH, Sinurat AP. 2015. Performa itik petelur PMp dengan pemberian ransum berbeda kadar energi dan lisin selama sepuluh bulan produksi. Dalam: Prosiding Seminar Nasional Peternakan Berkelanjutan 7. Sumedang (Indonesia): Fakultas Peternakan, UNPAD.

Pingel H. 2011. Waterfowl production for food security. Lohmann Information. 46:32-42

SAS. 1997. SAS/STAT guide for personal computers. Ver:6.12 Edit. SAS Institute Inc. Cary, NC.

Shelton JL, Mavromichalis I, Payne RL, Southern LL, Baker DH. 2003. Growth performance of different breed crosses of chicks fed diets with different protein and energy sources. Poult Sci. 82:272-278.

Xie M, Jiang Y, Tang J, Wen ZG, Huang W, Hou SS. 2014. Effect of stocking density on growth performance, carcass traits, and foot pad lesions of white Pekin ducks. Poult Sci. 93:16441648.

Xie M, Guo Y, Zhang T, Hou S, Huang W. 2009. Lysine requirement of male white Pekin ducklings from seven to twenty-one days age. Asian-Aust J Anim Sci. 22:1386-1390. 